\title{
The petroglyphs of Toro Muerto: new documentation and discoveries at the largest South American rock art complex
}

Janusz Z. Wołoszyn ${ }^{1, *}$, Liz Gonzales Ruiz ${ }^{2} \&$ Andrzej Rozwadowski ${ }^{3}$

Detailed documentation of thousands of petroglyphs and recent excavations conducted at the site of Toro Muerto in Peru reveal new information about the symbolic spatial organisation and ritual functions of the largest pre-Columbian rock art complex.

Keywords: Peru, Toro Muerto, pre-Columbian, petroglyphs, rock art

Toro Muerto, located in the desert of the Majes River Valley in southern Peru, is one of the largest and most impressive rock art complexes in the Americas (Figure 1). Most of its petroglyphs were probably created between the last centuries $\mathrm{BC}$ and the early centuries $\mathrm{AD}$, but it is evident that there was also activity at the site in the subsequent pre-Columbian period (Juszczyk et al. 2018). In colonial times_-and certainly from the beginning of the eighteenth century AD—some of Toro Muerto's decorated volcanic tuff boulders were used as building material by the valley's inhabitants. A significant portion of the site was also gradually modified through conversion into cultivated fields. Consequently, by the time that its archaeological significance was discovered in the early 1950s, Toro Muerto had already undergone considerable change and partial destruction. The site was discovered by Peruvian archaeologist Eloy Linares Málaga, who made the first plan of the southern part of the site, proposed its tentative - and relatively late - chronology, and estimated the number of decorated boulders at nearly 5000 (which was, in fact, almost double the actual figure). In the following decades, the complex was visited and studied by various scholars, both from Peru and abroad (Núnez 1986; van Hoek 2003; Díaz Rodríguez \& Rosińska 2008; Linares 2014). Four years ago, a Polish-Peruvian team led by archaeologists from the Institute of Archaeology of the University of Warsaw began to explore the site in order to prepare a detailed documentation of it that would meet modern standards and as an introduction to analytical research aimed at establishing the chronology of the creation and use of the site (analysis of the iconography of the complex), recognition of its functions and ways of use (excavations at certain boulders) (Juszczyk et al. 2018).

Toro Muerto is an extremely rich repository of rock art. The officially protected area covers almost $50 \mathrm{~km}^{2}$. Its central zone, where, according to our calculations, more than 95 per cent

1 Institute of Archaeology, University of Warsaw, ul. Krakowskie Przedmiéscie 26/28, Warsaw 00-927, Poland

2 Independent Researcher and Peruvian Co-Director of the Toro Muerto Archaeological Research Project

3 Faculty of Archaeology, Adam Mickiewicz University in Poznań, ul. Uniwersytetu Poznańskiego 7, Poznan 61-614, Poland

* Author for correspondence (Email: januszwoloszyn@uw.edu.pl)

(C) Antiquity Publications Ltd, 2019

ANTIQUITY 93 372, e37 (2019): 1-8

https://doi.org/10.15184/aqy.2019.200 
Janusz Z. Wołoszyn et al.

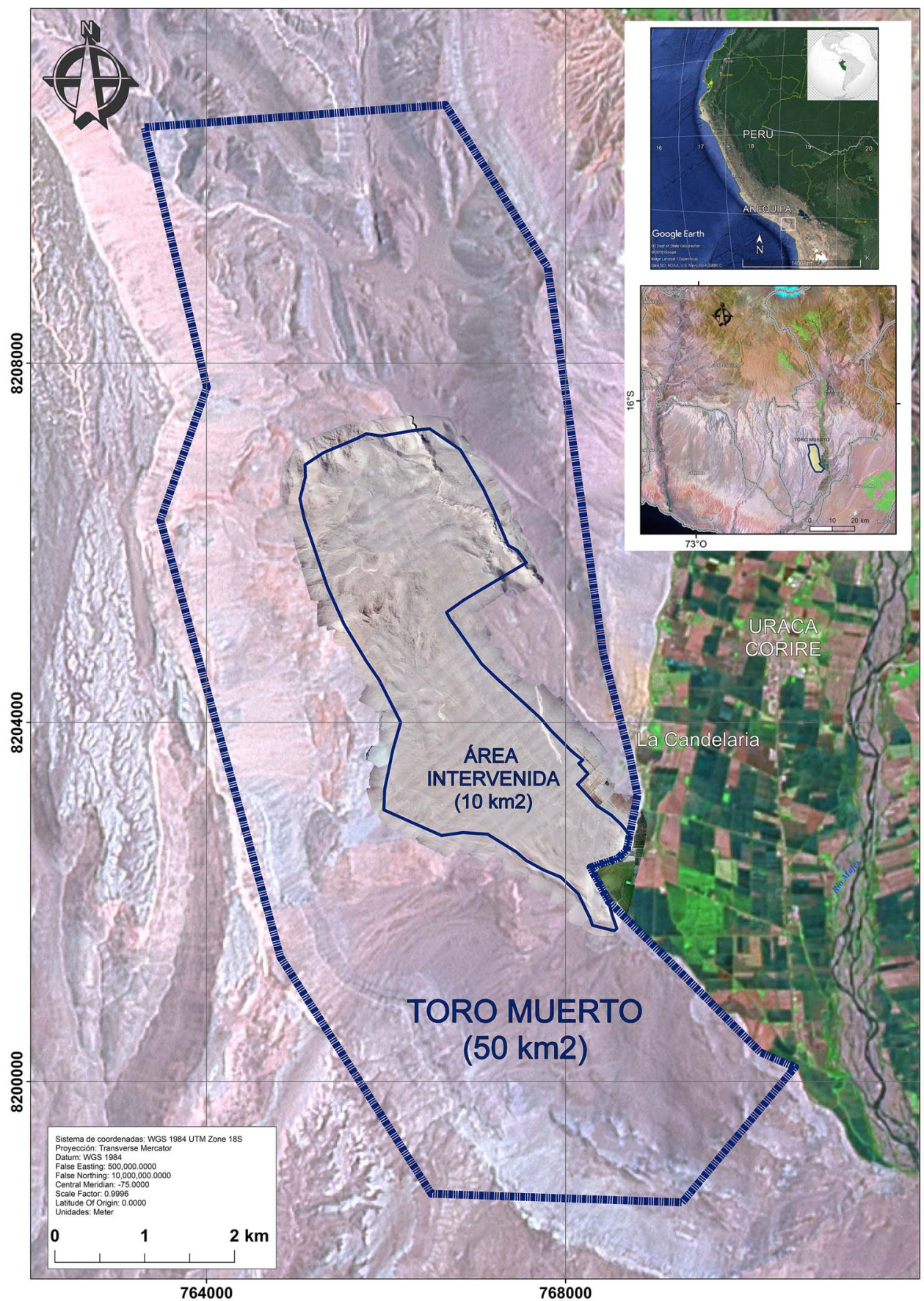

Figure 1. Left) location of the Toro Muerto rock art complex; right) general view of the site (figure credit: the Toro Muerto Archaeological Research Project Archive).

(C) Antiquity Publications Ltd, 2019 
of the decorated rocks are located, occupies over $10 \mathrm{~km}^{2}$. Although researchers have previously attempted to document the Toro Muerto petroglyphs (e.g. Pozzi-Escot 2009), they usually had the resources to record only a few hundred rocks. The documentation of the site has therefore remained incomplete and inaccurate. These inaccuracies can be observed in some of the published depictions of the petroglyphs, which are often free-hand drawings or based on oblique photographs, and are consequently heavily distorted. Furthermore, particular motifs from individual panels have often been presented separately, making it impossible to understand their relationship to other images on given panels.

The first stage of our project aimed to produce up-to-date documentation of the site, both on a macro and microscale. Due to the abundance of petroglyph-bearing boulders and their uneven distribution, this task required three field seasons to complete. More than $10 \mathrm{~km}^{2}$ of the Toro Muerto area was documented through surface survey, and almost 2600 decorated rocks were registered. The location of each boulder was recorded using a total station and GPS mapping, with each petroglyph photographed and described in detail. Many petroglyph panels were traced on a transparent paper overlay, and some rocks were surveyed to create 3D models (Figure 2). During the 2018 field season, and with the generous cooperation of the National Geographic Institute of Peru, we obtained the first high-resolution aerial photographs showing the entire study area. In the same year, we also documented a new sector of the site (provisionally named sector $\mathrm{X}$ ), which we discovered at an isolated hill located to the north. This site had almost 100 boulders decorated with unique iconography (Figure 3).

As part of the current phase of research, the Toro Muerto iconography has been analysed to consider similarities and differences in motifs, and to identify patterns and relationships between them-both on individual boulders and across the site. In terms of spatial arrangement, the boulders that have petroglyphs form an uneven strip along a south-north axis. Although many boulders are decorated, some bear no imagery, even if they are large enough and have surfaces suitable for making petroglyphs. Certain motifs can be seen in concentrations in various parts of the site, which may indicate the use of particular sectors for specific activities or rituals. These clusters include geometric designs, such as zigzags, as well as images of different kinds of birds and animals (e.g. snakes, felines or Andean camelids), and various anthropomorphic figures. The images of what appear to be people dancing, which are very characteristic of Toro Muerto and unique in Peruvian rock art, are present throughout almost the entire site, apart from the newly discovered sector X (Figure 4). A significant proportion of another type of human figure motif, depicting individuals with heads adorned with feathers, is clustered around an area that is free of boulders, creating a square or arena. It is also clear that certain motifs prevail in the eastern part of the complex, while others are found mainly on the western side.

In 2018, we also undertook small-scale excavations that revealed an abundance of offerings deposited next to some of the boulders (Figure 5). The material comprised edible plants (predominantly corn but also chilli peppers and peanuts), camelid and guinea pig remains, along with small, painted stone tablets (Figure 6). The latter are typical of archaeological sites in this region, but were probably deposited several hundred years after most of the petroglyphs were produced (Faron-Bartels 2011). This suggests that Toro Muerto continued to be visited in the following centuries and maintained its status as an important site. This

(C) Antiquity Publications Ltd, 2019 


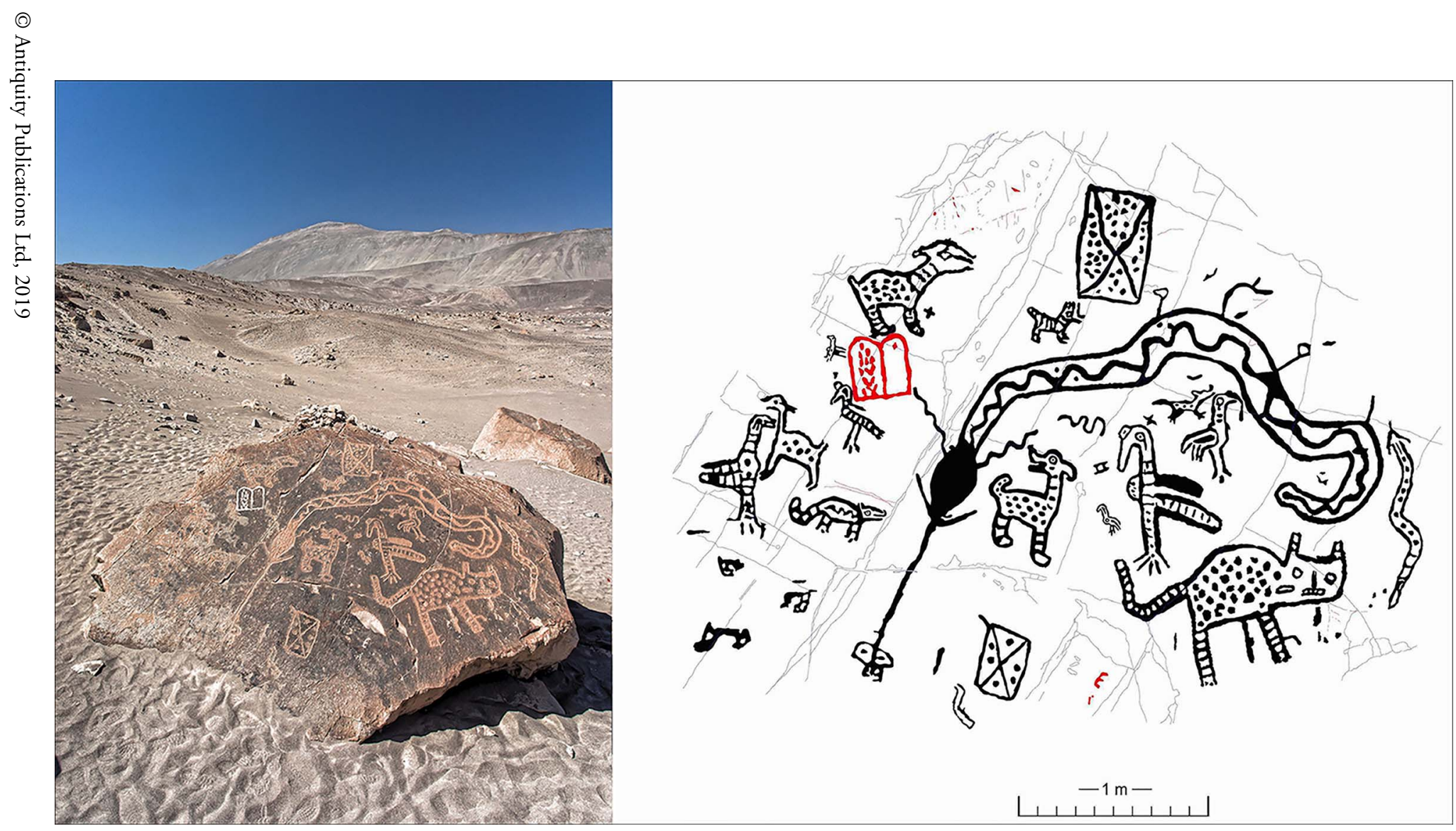

Figure 2. Left) Toro Muerto boulder TM 1677 exhibiting particularly rich iconography; right) modern graffiti (in the form of Tablets of Stone) is marked with a red line (figure credit: the Toro Muerto Archaeological Research Project Archive). 


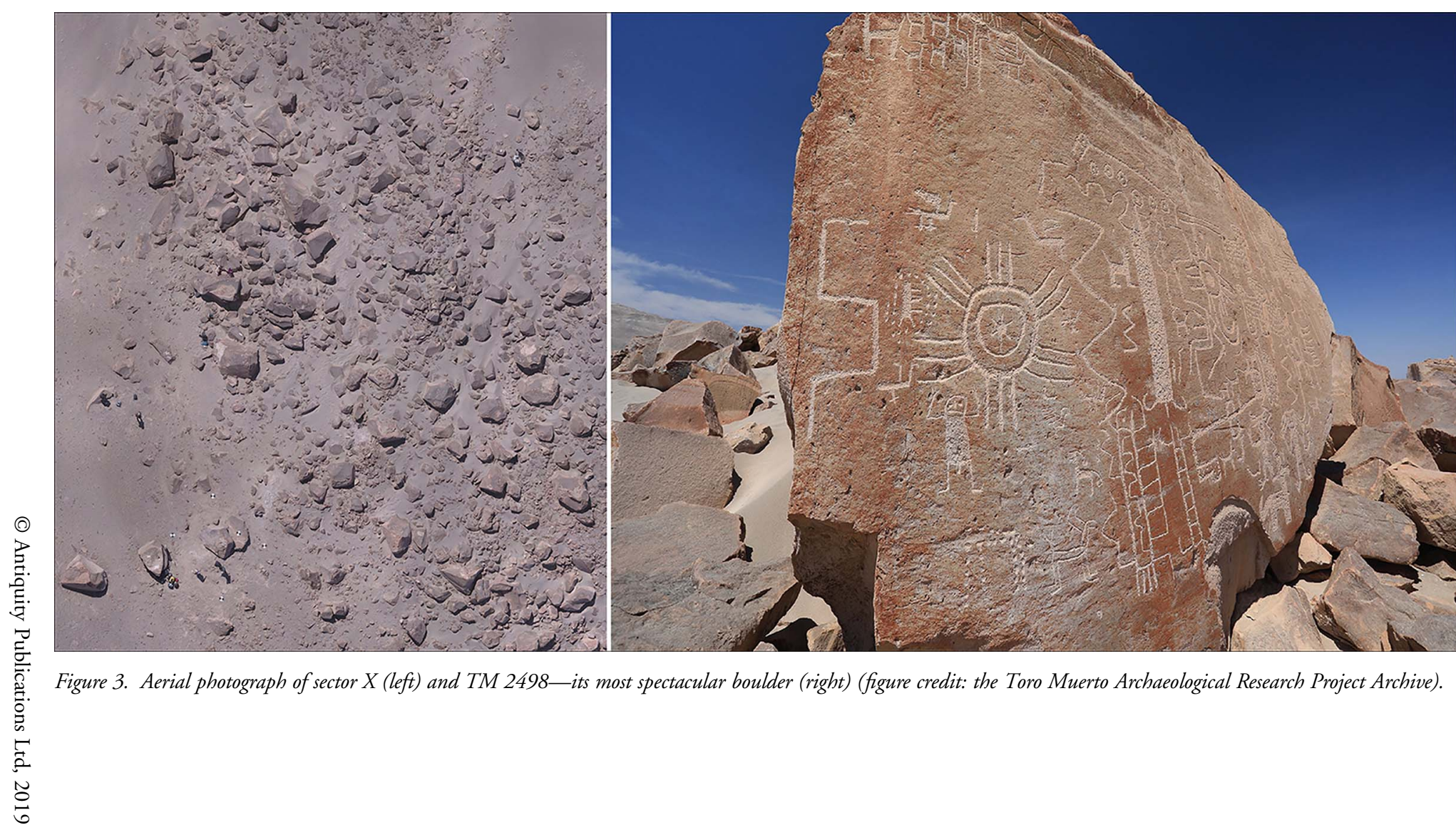

\section{Project Gallery}




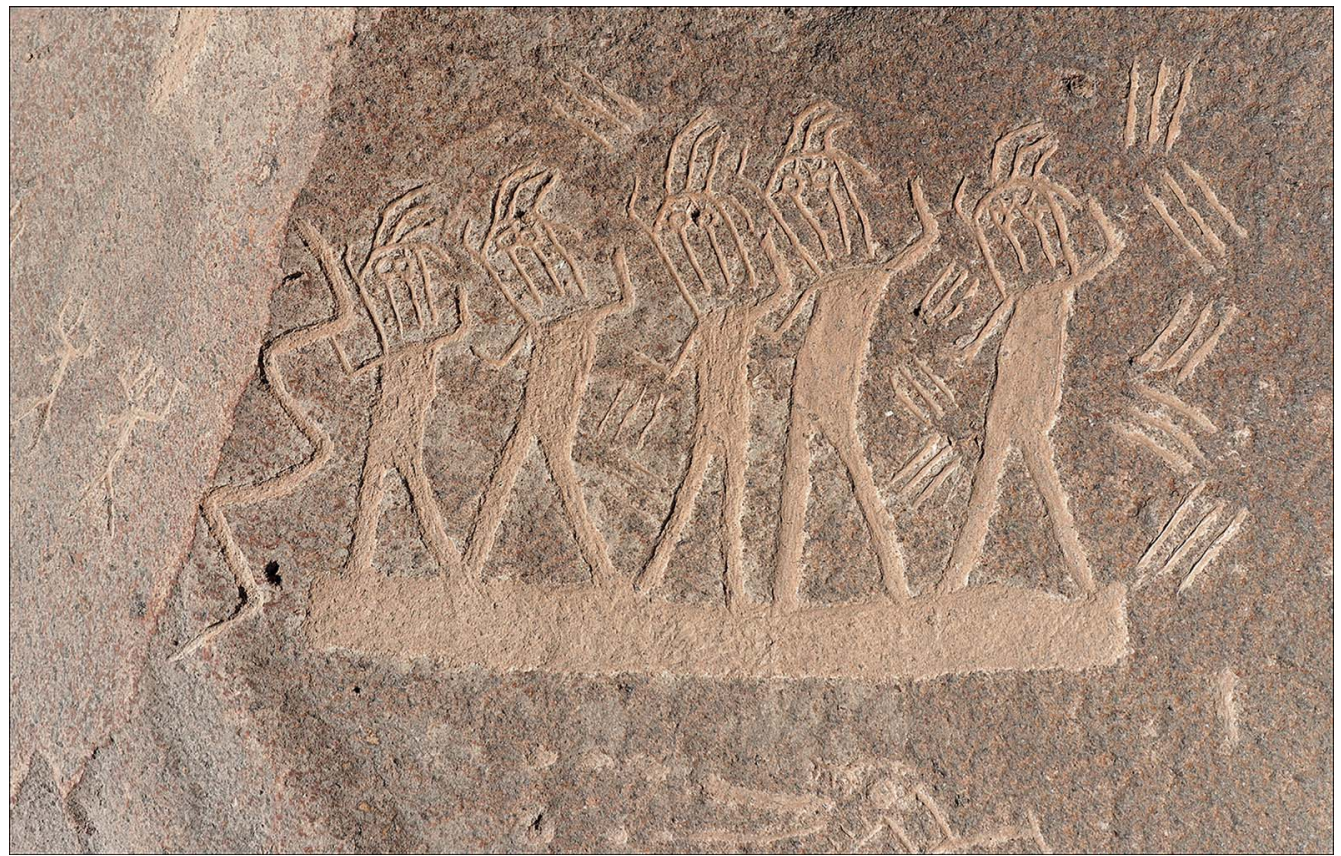

Figure 4. The 'dancer' is one of the most common motifs in Toro Muerto iconography (TM 1646) (figure credit: the Toro Muerto Archaeological Research Project Archive).

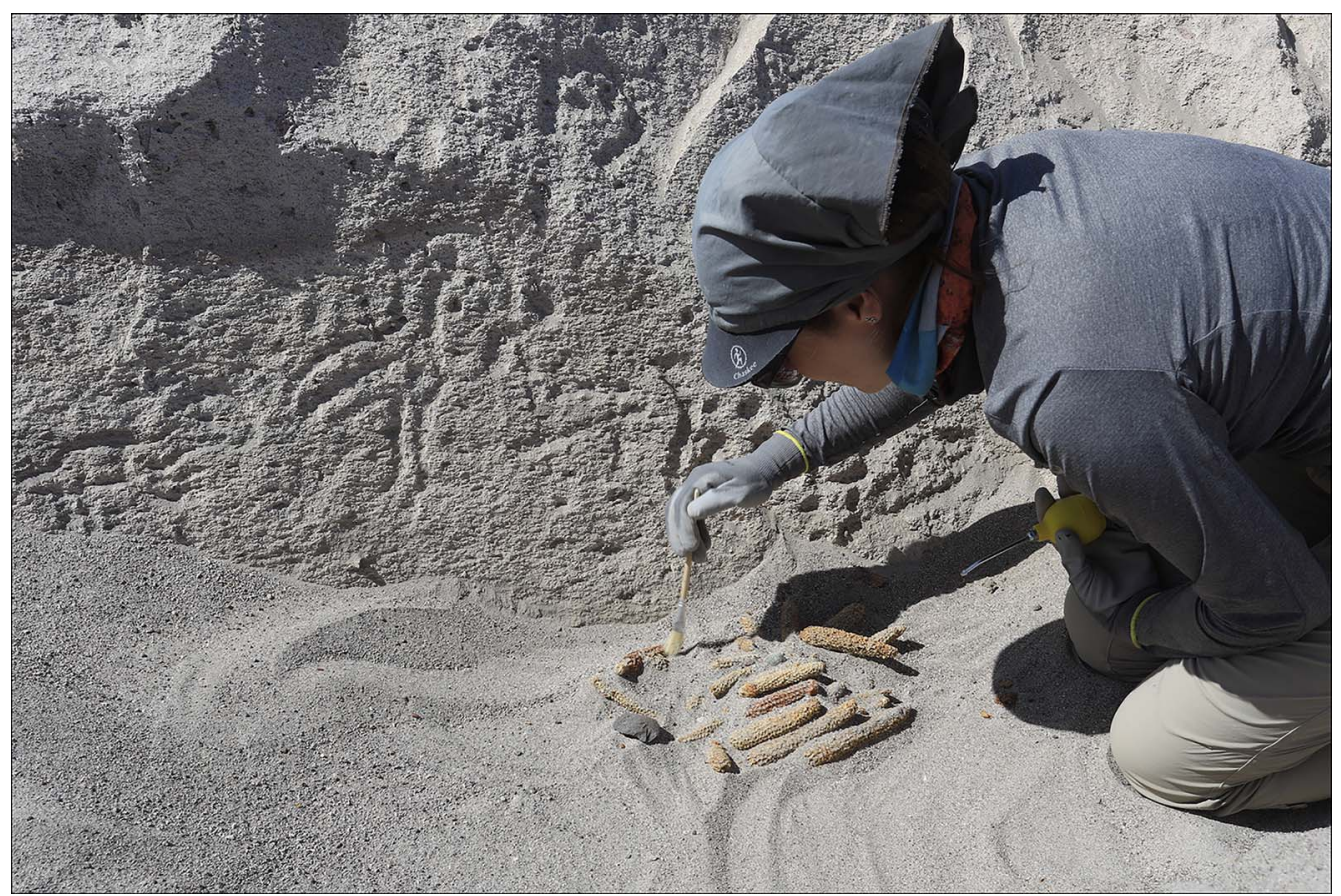

Figure 5. Excavating an offering of corncobs deposited adjacent to boulder TM 0252 (figure credit: the Toro Muerto Archaeological Research Project Archive).

(C) Antiquity Publications Ltd, 2019 


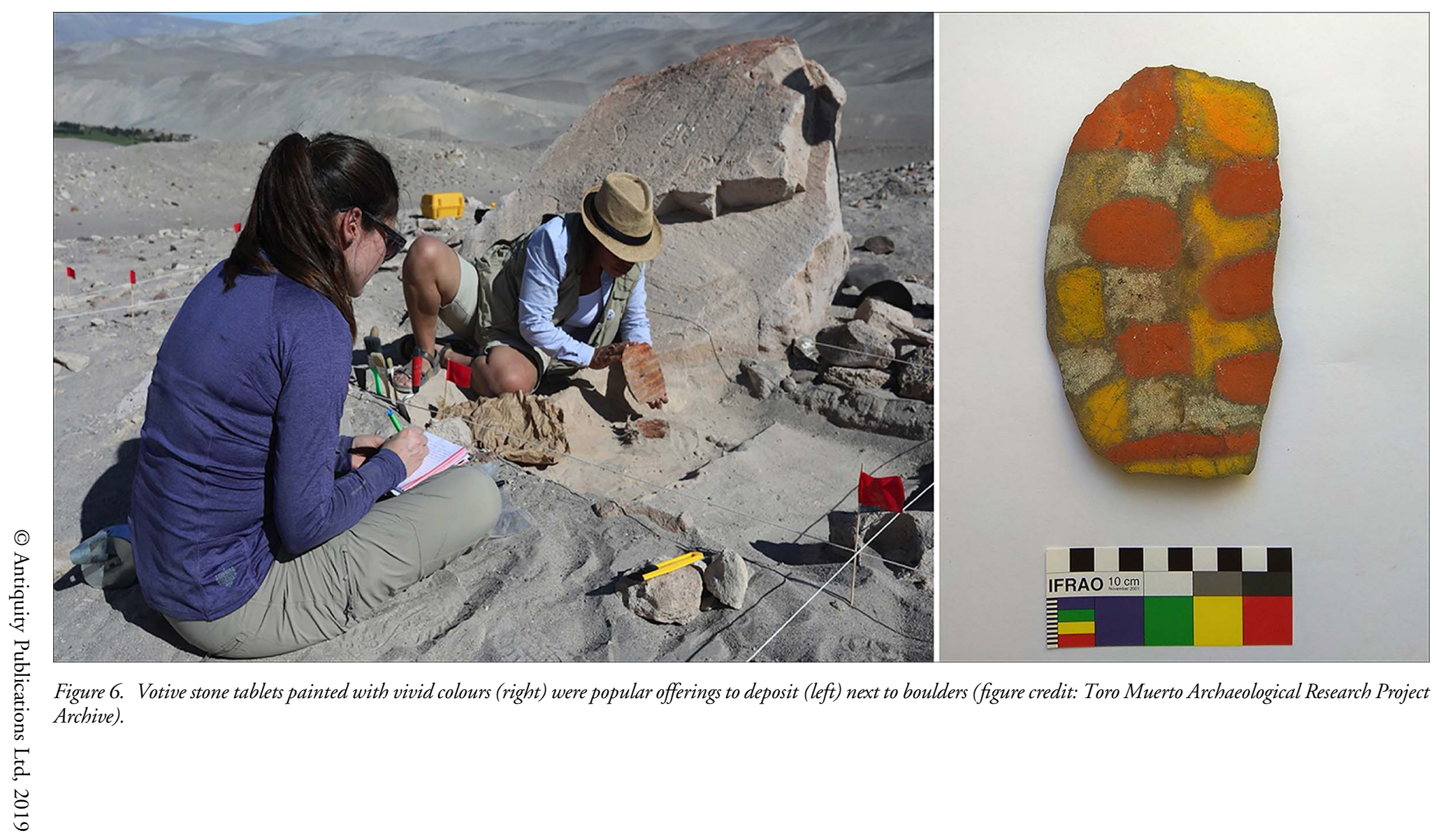


use of the site correlates with a widespread Andean tradition of wakas-sacred places that, to this day, still serve as portals through which interaction with the spirit world is possible. The organic materials are currently being dated, and we hope that this will increase our understanding of the site.

During his research in 1965, French archaeologist Henry Reichlen documented significant quantities of surface material at Toro Muerto. This included stone tools, obsidian blades, painted tablets and pottery sherds representing different cultures. Reichlen's photographs are currently stored in the archives of the Musée de quai Branly in Paris, and can be viewed via the museum's online catalogue. Today, the surface material has almost entirely disappeared. In the 70 years since its discovery, the site has attracted tourists in increasing numbers, which may have contributed to the disappearance or destruction of the material. Furthermore, this increase in tourism has also resulted in damage to the complex: modern graffiti, for example, have appeared on some boulders, particularly in the southern area (Figure 2). Recently, local authorities, together with Peruvian archaeologists and private investors, have tried to increase public understanding of Toro Muerto and to improve the amenities at the site. They are also petitioning UNESCO to make this magnificent complex a World Heritage Site.

\section{Acknowledgements}

The first stage of our research (2015-2016) was funded by the Polish Ministry of Science and Higher Education (DI 2013008843). Toro Muerto Archaeological Research Project (begun in 2017 and due to be completed in 2021) is funded by a National Science Centre grant (UMO-2016/23/B/HS3/01882). We would like to express our gratitude to Fabian Brondi Rueda and his team from the National Geographic Institute of Peru, and to Abraham Imbertis Herrera and Lesly Tapia Rubina from Arqueomática for their commitment and excellent work. Our special thanks go to Beata Jurkiewicz, Aleksandra Lisek, Emily Ramirez and all the volunteers from Peru, Chile and Mexico who joined us during the last two field seasons.

\section{References}

Díaz Rodríguez, L.H. \& D. RosińsKa. 2008.

Diversidad arqueológica en Toro Muerto, sur del

Perú. Tambo. Boletín de Arqueología 1: 83-98.

Faron-Bartels, R. 2011. Piedras votivas de

Pampacolca. Nuevos datos sobre las lajas pintadas

del sur del Perú. Unpublished PhD dissertation,

Freie Universität Berlin.

van Hoek, M. 2003. The rock art of Toro Muerto,

Peru. Rock Art Research 20-22: 151-70.

JuszczyK, K., J.Z. Wołoszyn \& A. RozWAdowsKi.

2018. Documentando Toro Muerto (Arequipa,

Perú): informe de las temporadas 2015-2017.

Boletín SIARB 32: 36-42.
Linares Málaga, E. 2014. Cómo inventariar arte rupestre en los Andes Meridionales. Boletín APAR 19-20: 831-86.

Núñez Jiménez, A. 1986. Petroglifos del Perú, volume 4. Havana: Editorial Científico-Técnica, UNESCO.

Pozzi-Escot, M. 2009. Los petrogifos de Toro Muerto (Valle de Majes, Arequipa-Perú): inventario y registro, in M. Sepúlveda, L. Briones \& J. Chacama (ed.) Crónicas sobre la piedra: Arte Rupestre de las Américas. VII Simposio Internacional de Arte Rupestre: 349-61. Arica: Universidad de Tarapacá.

Received: 9 June 2019; Revised: 18 June 2019; Accepted: 26 June 2019

(C) Antiquity Publications Ltd, 2019 